\title{
成人に拉ける睡眠時呼吸障害検査の検討
}

\author{
近藤 昭男 ${ }^{1)} \cdot$ 中村 克彦 1$) \cdot$ 上枝 亿美 ${ }^{1)} \cdot$ 奈賀 雅子 ${ }^{1)}$

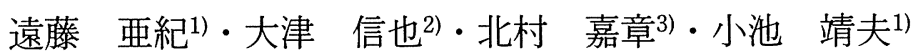

\section{Evaluation of Polysomnography in Adults}

\author{
Akio Kondo, Katsuhiko Nakamura, Hitomi Ueeda, Masako Naka, \\ Aki Endo and Yasuo Koike \\ (The University of Tokushima School of Medicine) \\ Shin-ya Otsu \\ (Kochi Red Cross Hospital) \\ Yoshiaki Kitamura \\ (Komatsushima Red Cross Hospital)
}

\begin{abstract}
Polysomnography is one of the most useful diagnositc methods for detecting sleep apnea syndrome (SAS). The subjects consisted of 30 adult patients suffering from snoring or sleep apnea. In order to diagnose the location of stenosis and severity of SAS, the mesopharyngeal pressure amplitude (MPA), lowest $\mathrm{SaO}_{2}$ and apnea index (AI) are analyzed. $\mathrm{AI}<5$ is defined the snoring group, and $\mathrm{AI} \geqq 5$ defined the SAS group. The MPA obtained in the SAS group was higher than in the snoring group $(\mathrm{P}<0.01)$. The lowest $\mathrm{SaO}_{2}$ obtained in the $\mathrm{SAS}$ group was lower than in the snoring group $(\mathrm{P}<0.01)$.
\end{abstract}

Key words : polysomnography, sleep apnea syndrome, mesopharyngeal pressure amplitude, lowest $\mathrm{SaO}_{2}$

\section{はじめに}

睡眠時無呼吸症候群の概念は1970年代頃に報告され， その後多く検討されてきている.1976年, Guilleminault ら日)によれば, 睡眠時無呼吸症候群 (sleep apnea syndrome) とは，睡眠中に換気がとまる現象で， 7 時間の 睡眠中に 10 秒以上続く換気停止が30回以上，または 1 時 間あたり 5 回以上抽こり，それにより臨床症状を呈する 状態であると定義している。これまで, 徳島大学では, 圧トランスデューサーを用い，中咽頭圧を測定し，それ を指標に口蓋扁桃摘出術などの手術療法の適応を決定し てきた2) 4).しかし，いびき，睡眠時無呼吸があるのに，
中咽頭圧が上昇していない症例を経験することがあるし， 逆に睡眠時無呼吸はないのに，中咽頭圧の上昇している 症例も経験することがある。 また, 最近, 他施設からパ ルシオキシメーターを使用して, 睡眠時無呼吸の簡易検 查法を施行した報告5)6) がある. しかし, その問題点と して, 酸素飽和度が低下し, 臨床的に睡眠時無呼吸を呈 していても，具体的な病態を十分把握できていないと思 われる、つまり, 睡眠時無呼吸が閉塞型か中枢型か, あ るいは, 閉塞型なら閉塞部位はどこになるのかなどにつ いて，不明な点が多いと思われる，そこで，今回，最低 酸素飽和度といらパラメーターを設定し, 成人に批ける

1) 徳島大学医学部耳鼻咽喉科学教室

2）高知赤十字病院耳鼻咽喉科

3）小松島赤十字病院耳鼻咽喉科 
いびき症, 睡眠時無呼吸症候群と中咽頭圧, 最低酸素飽 和度の関係について検討したので報告する。

\section{対 象}

平成 9 年 4 月から平成 10 年 3 月までに，いびきまたは 睡眠時無呼吸などの気道狭窄症状を主訴に徳島大学医学 部附属病院耳鼻咽喉科を受診した症例のらち，20歳以上 で睡眠ポリグラフ検査を施行し, 中咽頭圧と睡眠時酸素 飽和度を測定できたもの30例を対象とした．年齢は 26 歳 より68歳までで, 男性23例(平均年齢士標準偏差 : 49.3 \pm 12.5 歳), 女性 7 例 (平均年齢士標準偏差 : $48.3 \pm 15.6$ 歳)であった。

\section{方 法}

睡眠ポリグラフの内容は, 中咽頭圧, 鼻・口腔よりの 換気気流, 胸腹部の呼吸運動, 経皮的動脈血酸素飽和度 を終夜にわたり測定した. 中咽頭圧は, 石田 ${ }^{2)}$ の中咽頭 圧検査法に基づき，超小型圧トランスデューサー(Gaeltec 社製 12D-105）を経鼻的に挿入し，口蓋扁桃直下付近の 咽頭腔に留置した. 気道内圧変化を導出, 記録し, 呼気 時と吸気時の圧変化の最大振幅の絶対値を測定し, 中咽 頭圧值とした。換気気流は, 鼻・ 口腔マスクを顔面に固 定し，それに接続したサーミスタにより気流の温度变化 をとらえ気流の示標とした。胸腹部の呼吸運動は, スト レインゲイジを胸部もしくは腹部周囲に装着し, 周囲径 の変化を測定し, 呼吸運動の指標とした. 経皮的動脈血 酸素飽和度は, 酸素飽和度をデジタルに記録でき, 後の 解析が容易なアプノモニターII (Chest 社製)を使用した。 アプノモニターIIのパルシオキシメーターを手指に装着 し，測定した。

今回の検討では，換気気流よりみて，睡眠中の 10 秒以 上の換気気流の停止を無呼吸と定義し, 睡眠 1 時間あた りの呼吸停止回数を無呼吸指数 (apnea index, 以下 AI と略す)に求め, AIが 5 未満をいびき群, AIが 5 以上 を睡眠時無呼吸群とした。いびき群は18例, 睡眠時無呼 吸群は12例となった(表 1 ).

\section{結 果}

いびき群と睡眠時無呼吸群の中咽頭圧值の分散が等し いかどらかを $\mathrm{F}$ 検定を用いて検定すると，分散が等しく なかった。よって，いびき群と睡眠時無呼吸群の中咽頭 圧值の差の検定は, Mann-Whitney Test 法を用いて検
定した。

同じようにいびき群と睡眠時無呼吸群の最低酸素飽和 度の分散が等しいかどらかを $\mathrm{F}$ 検定を用いて検定すると， 分散が等しくなかった。 よって，いびき群と睡眠時無呼 吸群の最低酸素飽和度の差の検定は, Mann-Whitney Test 法を用いて検定した。

$1 ：$ :びき群の中咽頭圧値は， $5 \sim 57 \mathrm{cmH}_{2} \mathrm{O}$ にわた り, 平均中咽頭圧值士標準偏差は $28.7 \pm 15.5 \mathrm{~cm} \mathrm{H}_{2} \mathrm{O}$ で あった。 睡眠時無呼吸群の中咽頭圧値は $5 \sim 103 \mathrm{cmH}_{2} \mathrm{O}$ にわたり，平均中咽頭圧值士標準偏差は $61.0 \pm 32.4$ $\mathrm{cmH}_{2} \mathrm{O}$ であった. 図 1 のごとく, 睡眠時無呼吸群の中 咽頭圧值がいびき群に比べて有意に高かった $(\mathrm{P}<0.01)$.

2 : いびき群の最低酸素飽和度は，67９7\%にわたり， 平均最低酸素飽和度土標準偏差は87.8土6.8\%であった。 睡眠時無呼吸群の最低酸素飽和度は，52〜90\%にわたり， 平均最低酸素飽和度土標準偏差は72.8 $14.0 \%$ であった。 図 2 のごとく, 睡眠時無呼吸群の最低酸素飽和度がいび き群に比べて有意に低かった $(\mathrm{P}<0.01)$.

3 : 全症例に括ける中咽頭圧值と最低酸素飽和度に ついて，スピアマンの順位相関係数を求めると, $\mathrm{r}_{\mathrm{s}}=$ $-0.408, \mathrm{P}<0.05$ であった(図 3 ).

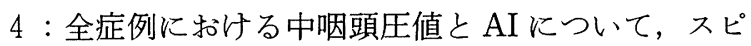
アマンの順位相関係数を求めると, $\mathrm{r}_{\mathrm{s}}=0.533, \mathrm{P}<0.01$ であった(図 4).

5 ：全症例に打ける最低酸素飽和度と AI について， スピアマンの順位相関係数を求めると, $\mathrm{r}_{\mathrm{s}}=-0.534$, $\mathrm{P}<0.01$ であった(図 5 ).

\section{考察}

睡眠時無呼吸症候群の患者は, 循環器系の障害を合併 していることが多(、78). 睡眠時の頻回な無呼吸発作が 低酸素血症を起こし，それが高血圧症，不整脈を引き起 こす原因ともなりえる，そこで，飛田ら5) は閉塞型睡眠 時無呼吸症候群患者において, 無呼吸回数, および同一 患者に佂ける 1 回無呼吸持続時間と最低酸素飽和度の間 に有意な逆相関があると報告した。しかし，パルシオキ シメーターのみの判定では，上気道のどの部位が閉塞し ているのかについての診断が不十分であったり，睡眠時 無呼吸が閉塞型か中枢型かは不明である。一方，中咽頭 圧值の測定について，武市 ${ }^{3)}$ は小児の睡眠時呼吸障害の 重症度, 部位診断に拈いて, 簡便で有用な検查であると 報告している。また，和田ら ${ }^{4)}$ は，小児の睡眠時呼吸障 
表 1 全症例の測定結果

\begin{tabular}{|c|c|c|c|c|c|}
\hline 症例 & 性別 & 年齢 & $\begin{array}{c}\text { 中咽頭圧值 } \\
\left(\mathrm{cmHH}_{2} \mathrm{O}\right)\end{array}$ & $\begin{array}{c}\text { 最低酸素飽和度 } \\
(\%)\end{array}$ & apnea index \\
\hline 1 & 男性 & 36 & 76 & 62 & 83.6 \\
\hline 2 & 男性 & 49 & 49 & 68 & 34.3 \\
\hline 3 & 男性 & 56 & 38 & 61 & 22.8 \\
\hline 4 & 男性 & 32 & 71 & 70 & 21.0 \\
\hline 5 & 男性 & 47 & 41 & 90 & 19.7 \\
\hline 6 & 女性 & 43 & 92 & 65 & 19.2 \\
\hline 7 & 男性 & 33 & 95 & 52 & 19.0 \\
\hline 8 & 男性 & 31 & 22 & 82 & 15.5 \\
\hline 9 & 男性 & 58 & 101 & 89 & 14.6 \\
\hline 10 & 男性 & 61 & 103 & 87 & 10.3 \\
\hline 11 & 男性 & 32 & 22 & 57 & 7.3 \\
\hline 12 & 男性 & 37 & 22 & 90 & 5.1 \\
\hline 13 & 男性 & 38 & 41 & 89 & 2.7 \\
\hline 14 & 女性 & 43 & 57 & 67 & 2.3 \\
\hline 15 & 男性 & 46 & 16 & 94 & 2.0 \\
\hline 16 & 男性 & 65 & 19 & 89 & 1.4 \\
\hline 17 & 女性 & 62 & 38 & 93 & 1.0 \\
\hline 18 & 男性 & 54 & 16 & 89 & 0.9 \\
\hline 19 & 男性 & 60 & 44 & 87 & 0.6 \\
\hline 20 & 女性 & 35 & 38 & 79 & 0.3 \\
\hline 21 & 男性 & 45 & 27 & 89 & 0.3 \\
\hline 22 & 男性 & 66 & 19 & 86 & 0.3 \\
\hline 23 & 男性 & 66 & 16 & 82 & 0.3 \\
\hline 24 & 女性 & 68 & 52 & 93 & 0 \\
\hline 25 & 男性 & 66 & 41 & 92 & 0 \\
\hline 26 & 男性 & 40 & 41 & 85 & 0 \\
\hline 27 & 女性 & 61 & 27 & 89 & 0 \\
\hline 28 & 男珄 & 55 & 11 & 88 & 0 \\
\hline 29 & 男性 & 61 & 8 & 93 & 0 \\
\hline 30 & 女性 & 26 & 5 & 97 & 0 \\
\hline
\end{tabular}

症例 $1 \sim 12$ は睡眠時無呼吸群, 症例13〜30はいびき群

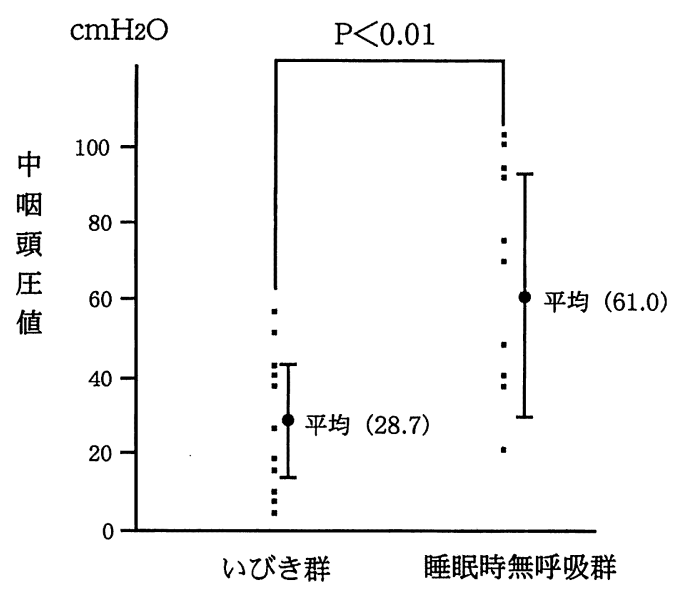

図 1 いびき群と睡眠時無呼吸群の中咽頭圧值について

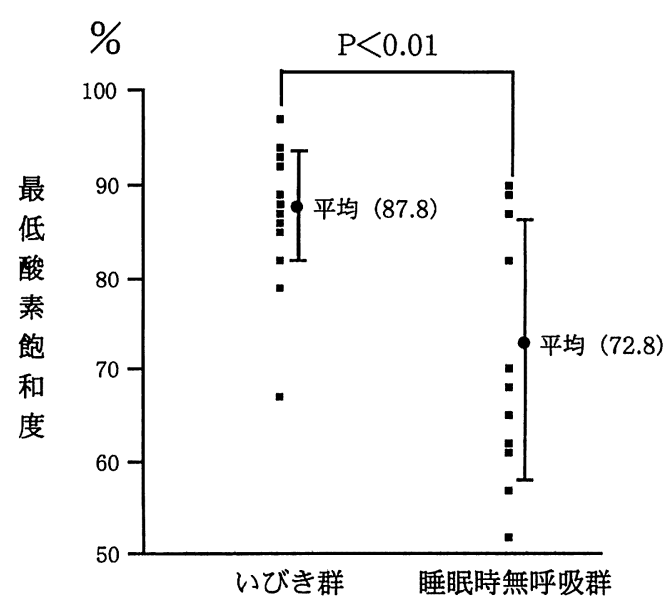

図 2 いびき群と睡眠時無呼吸群の最低酸素飽和度について 


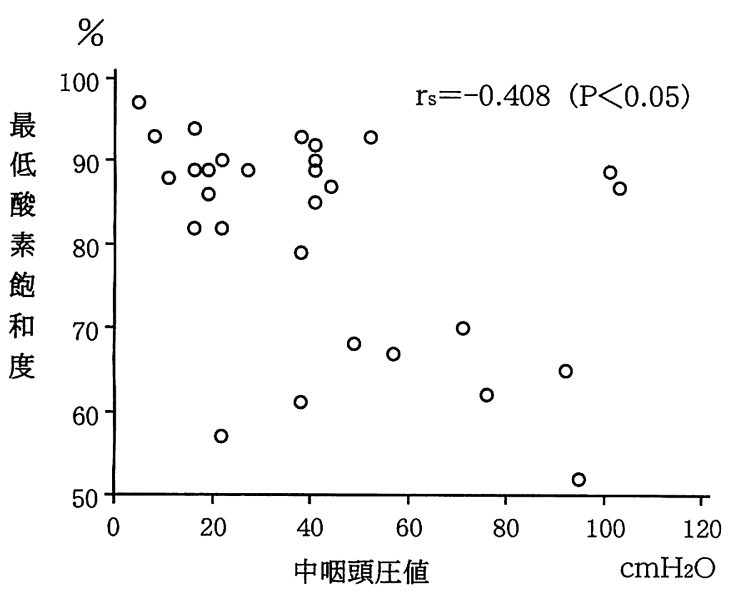

図 3 中咽頭圧值と最低酸素飽和度の関係

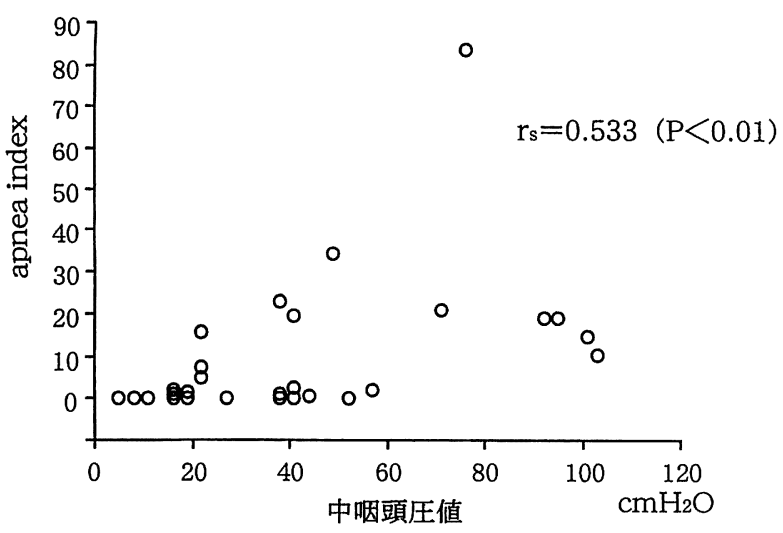

図 4 中咽頭圧值と apnea index の関係

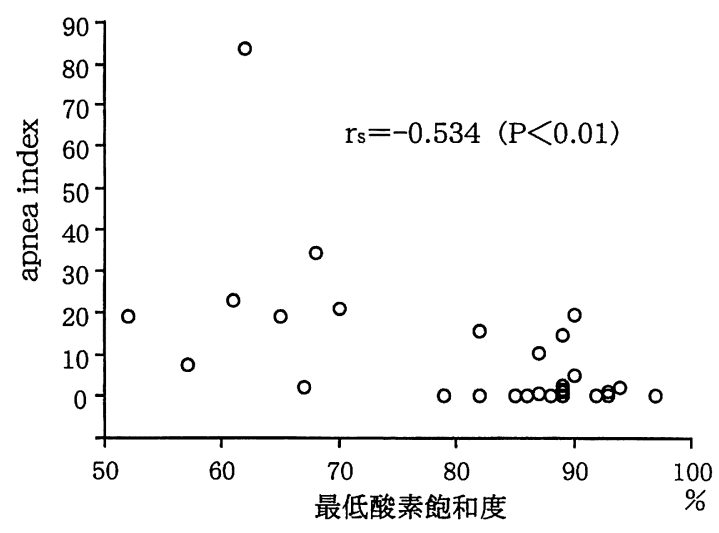

図 5 最低酸素飽和度と apnea index の関係

害の重症度分類には AI, 最低酸素飽和度などの指標に 比して, 中咽頭圧值が有用であると報告している. しか
し，いびき，睡眠時無呼吸があるのに，中咽頭圧が上昇 していない症例を経験することがあるし，逆に睡眠時無 呼吸はないのに, 中咽頭圧の上昇している症例も経験す ることがある．また，中咽頭圧值が成人の睡眠時無呼吸 の診断指標となりえるかどらかの報告がない.そこで, 今回は成人に拈けるいびき症, 睡眠時無呼吸症候群と中 咽頭圧，最低酸素飽和度の関係について検討した。

いびき群のなかで一つだけ，最低酸素飽和度がきわめ て低い症例があった(症例14). 中咽頭圧値が $57 \mathrm{cmH}_{2} \mathrm{O}$ で，最低酸素飽和度が $67 \%$ であった。中咽頭圧が上昇し て括り，相当の上気道狭窄を疑わせた。 そこで，検査時 のデータシートを再検討すをと, 換気気流が完全には停 止していないが，高度の低換気状態が頻回に出現してお り，単位時間当たりの無呼吸低呼吸指数 (apnea hypopnea index, 以下 AHI と略す)を計算すると, AHI は 36.3であった.よって，この症例は実は睡眠時無呼吸群 に含まれるべき症例であったと考えられたＡI に対し て，中咽頭圧値あるいは最低酸素飽和度が解離している 場合，診断に疑問が生じれば，低換気状態の回数を確認 しなければならないと思われた。

睡眠時無呼吸群で中咽頭圧值が飛び抜けて低い症例が あった(症例 $8 ， 11 ， 12$ ). これら 3 症例では, 中咽頭圧 值は $22 \mathrm{cmH}_{2} \mathrm{O}$ と高値を示さないのに, 睡眠時無呼吸 が存在していた。これは, 閉塞部位が舌根部にあると考 えられた、つまり，圧トランスデューサーをロ蓋扁桃直 下に留置しているので, 舌根部に閉塞がある場合は, 舌 根部から気管側の陰圧負荷が増加し, 逆に口蓋扁桃から 軟口蓋にかけての陰圧負荷は増加しないのである．要す るに, 睡眠時無呼吸が存在し, 中咽頭圧值が上昇すると いらことは，狭窄部位がロ蓋扁桃部を中心とした軟口蓋 部にあり，睡眠時無呼吸が存在するのに，逆に中咽頭圧 值が低值といらことは，狭窄部位が舌根部にあるといら ことが推測される.このことは, 武市 ${ }^{3)} の 2$ 点咽頭圧検 査を施行することで上気道狭窄部位を診断できる. しか し，舌根部と口蓋扁桃部での圧差を測定するために，圧 トランスデューサーを経鼻的に 2 本挿入しなければなら ないので，患者にとっては負担になると思われる．そこ で, 中咽頭圧值, 最低酸素飽和度, および AI を見るこ とで, 狭窄部位, 睡眠時呼吸障害の程度を推測できると 思われる.さらに, このよらな症例に対する手術療法と して, 口蓋垂軟口蓋咽頭形成術 (uvulopalatopharyngoplasty : UPPP) のみでなく, 舌根部の狭窄があると診 
断された場合, 舌根正中部分切除術9) 11) (midline laserglossectomy：MLG)を加觉る必要があると術前に判断 できると思われる。また，中枢型の睡眠時無呼吸では， 中咽頭圧は上昇しないので，鑑別の一つとしなければな らないが，胸腹部の呼吸運動を見ることで除外できる. すなわち, 中枢型の場合，換気気流が停止している時と 同期して，胸腹部の呼吸運動も停止している。これより 閉塞型と鑑別できるはずである233.

睡眠時無呼吸群で中咽頭圧値が $100 \mathrm{cmH}_{2} \mathrm{O}$ と上昇し ているにもかかわらず，最低酸素飽和度が $80 \%$ 代後半の 症例があった(症例 9，10)。高度の上気道狭窄があるに も関わらず，最低酸素飽和度の低下は決して高度ではな かったし，AI も高度な範疇に入らなかった $(\mathrm{AI}: 14.6$ と10.3)。これらの症例は, 上気道狭窄が高度にも関わ らず，睡眠時無呼吸の程度が軽いと推測された。このよ らな場合は，すぐに手術療法をしなければならないとい らわけではないが，将来的に睡眠時無呼吸の程度が増大 してくる可能性があると思われるので, 厳重観察を必要 とする症例群と考光られる.

以上より，成人のいびき症，および睡眠時無呼吸では 中咽頭圧値のみ, あるいは最低酸素飽和度のみでは診断 を誤る恐れがある．しかし，両者を組み合わせることで 診断の誤りを防止できることが可能であると思われる. 今回の検討にて, 四 1，2上り睡眠時無呼吸群の特徵之 して, 中咽頭圧值が上昇して括り, 最低酸素飽和度が低 下していることが挙げられる．中咽頭圧值が上昇してい るといらことは, 上気道の狭窄があるといらことで，上 気道狭窄が睡眠時無呼吸を引き起こすと考兄られる。そ して, 睡眠時無呼吸に上る呼吸障害が，酸素飽和度の低 下をもたらすと推測できる．図 3 より中咽頭圧值が上昇 寸るほど，最低酸素飽和度が低下寸る傾向にある。上気 道狭窄の程度が増すほど, 呼吸障害の程度が増すことが 言える. 図 4 より中咽頭圧值が上昇する注ど，AI が増 加する傾向にあり, また図 5 より最低酸素飽和度が低下 するほど, AI が増加する傾向にある.よって, 中咽頭 圧值扣よび最低酸素飽和度を読み取ることで, 図 6 のよ らな診断表が考えられる. 中咽頭圧值の上昇を認めず, かつ最低酸素飽和度の低下がない場合は，正常もしくは 睡眠時無呼吸を伴わないいびき症を疑う。中咽頭圧值が 上昇して扣り，それに応じて酸素飽和度が低下している 場合，軟口蓋型の睡眠時無呼吸を疑い，中咽頭圧値ある いは最低酸素飽和度によって, 睡眠時無呼吸の程度を予

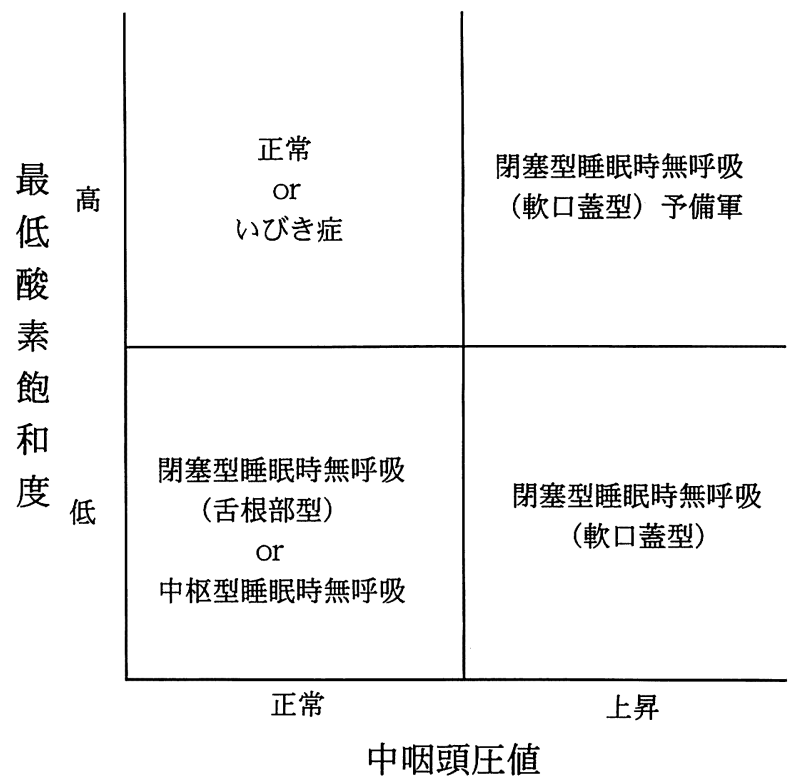

図 6 中咽頭圧值と最低酸素飽和度からの診断表

想できるであろう。それによって，手術時期などの決定 に役割を果たすと思われる.中咽頭圧值の上昇がなく, 最低酸素飽和度の低下がある場合, 舌根部型の睡眠時無 呼吸を疑う。よって, この場合には手術療法に UPPP に舌根正中部分切除術を加兄る必要があると思われる.

しかし, 閉塞部位が軟口蓋と舌根部の両方にある場合 や閉塞型と中枢型の両方が存在する混合型睡眠時無呼吸 の場合などについては図 6 からは診断できない問題点が あり，今後さらに症例を増やし検討しなければならない と思われる. 成人の睡眠時無呼吸の検査には, 狭窄部位, 睡眠時無呼吸の程度を推測するためには，中咽頭圧値， 最低酸素飽和度の両者が必要であり, 有用であると思わ れる.

$$
\text { まとめ }
$$

$1 ：$ :びき群と睡眠時無呼吸群の中咽頭圧值, 最低酸 素飽和度, AI そついて検討した。

2 : 中咽頭圧值は睡眠時無呼吸群の方がいびき群より 高かった.

$3:$ 最低酸素飽和度は睡眠時無呼吸群の方がいびき群 より低かった。

4: 中咽頭圧值と最低酸素飽和度は, 成人の睡眠時無 呼吸の狭窄部位，程度を検討するのに有用である。 


\section{参考文献}

1) Guilleminault C, Tilkian A and Dement WC : The sleep apnea syndromes. Ann Rev Med $27:$ 465 484, 1976.

2 ) 石田達也：上気道狭窄と中咽頭圧検査法. 耳鼻臨床 78 : $411 \sim 432,1985$.

3 ) 武市佳代子：小児に拈ける睡眠時呼吸障害の検討一扁桃 肥大児を中心として一。聑鼻 $91 ： 88 \sim 100,1988$.

4 ）和田好純, 武市佳代子, 宇高二良, 他 : 中咽頭圧上りみた 扁摘の適応. 日扁桃誌 $27: 217 \sim 222,1988$.

5 ) 飛田 渉, 岡部慎一, 佐藤 誠, 他: パルスオキシィーター 一睡眠時無呼吸モニター一。臨床モニター 1:123〜128， 1990.

6 ) Stradling JR and Crosby JH : Predictors and prevalence of obstructive sleep apnea and snoring in 1001 middle aged men. Thorax $46: 85 \sim 90,1991$.
7 ) 国枝武義 : 循環器系への影響. JOHNS 7 : 905 912, 1991.

8 ）柴田修宏, 西村忠郎, 森島夏樹, 他 : 睡眠呼吸障害に打け る夜間血圧への影響. 日耳鼻 $100: 678 \sim 684,1997$.

9 ) Fujita S, Woodson BT, Clark JL, et al : Laser midline glossectomy as a treatment for obstructive sleep apnea. Laryngoscope $101: 805 \sim 809,1991$.

10）藤田史郎：睡眠時無呼吸症候群の手術的治療. 耳喉頭頸 $61: 703 \sim 712,1989$.

11）武田広誠，甲斐智朗，小川 明, 他 : 睡眠時無呼吸に対す る舌根正中部分切除術. 耳鼻臨床 $90: 791 \sim 796,1997$.

$$
\left(\begin{array}{l}
\text { 別刷請求先 : 近藤昭男 } \\
\text { †770-8503 徳島市蔵本町 } 3 \text { 丁目 18-5 } \\
\text { 徳島大学医学部耳鼻咽喉科学教室 }
\end{array}\right)
$$

